\title{
CULTURAL POVERTY WITHIN THE LIFE OF HINDU POOR PEOPLE IN KARANGASEM REGENCY
}

\author{
IM Pidada Manuaba*, IBG Yudha Triguna, and IGB Wirawan \\ Universitas Hindu Indonesia \\ *<pidadamanuaba@yahoo.co.id>
}

\begin{abstract}
This study examines cultural poverty in the lives of economically poor Hindus in Karangasem Regency. Poverty is a serious problem in Karangasem Regency, such that until the present time Karangasem Regency occupies the top position as the region with the highest number of poor people in Bali Province. Various efforts have been made to alleviate poverty but the difficulty of poverty reduction in Karangasem Regency is inseparable from the occurrence of cultural poverty, such as the values, attitudes, and behavior of the poor who are, in this case, predominantly Hindus. This article discusses some of the reasons for the occurrence, forms and implications of cultural poverty.
\end{abstract}

Keywords: cultural poverty, poor people, Hindu names

\section{Introduction}

Karangasem Regency occupies the top position with the largest number of poor people in Bali Province, specifically, this number is $6.55 \%$ of the total population. Poverty is a multidimensional problem that requires greater systematic and integrated efforts in order to resolve it. Eradicating poverty in this level is no longer limited to meeting basic needs; its complexity needs constructive efforts to overcome the degradation of mental, moral and cultural values, attitudes and behavior. In this case, poverty appears as the inability to fulfil basic needs as well as the inability (of the community) to integrate with the wider community, such that the community becomes apathetic, pragmatic, fatalistic, has low 
education level, lacks fighting power and fails to think about the future. This condition, cultural poverty, is understood as poverty that is closely related to the culture of society so that it is often inherited from one generation to the next (Lewis, in Effendi, 1995).

The poverty can be categorized into three, namely (1) natural poverty, namely poverty caused by the limited quality of natural resources (SDA) and human resources (HR); (2) structural poverty, which is poverty caused by structural factors, namely the inability of social systems and structures to provide opportunities for the poor to earn income. And (3) religious poverty, namely poverty caused by wasteful lifestyle behaviors, low education level, inability to work, low interest in saving, resignation, apathy, feeling helpless, and cultural values that make someone feel comfortable with their poverty (Tim Penyusun, 2013: 4-5).

Looking at the three categories of the poverty there appears that the problem of poverty involves interrelated multiple factors. The initial search in the field of research shows that out of the three forms of poverty, the phenomenon of cultural poverty is quite dominant in Karangasem Regency. Given the same natural conditions in an area where the majority of the population is poor, the population is found to be rather economically successful. This confirms that the natural conditions are not the dominant factor causing poverty, but rather the values, attitude, behavior, and work ethic of each person.

In other words, poverty is not solely caused by limited access to the economy, markets, and literacy, but rather due to the values, outlook on life, and norms adopted by the community. This is confirmed by Gunawan (2010) that perceptions, emotions, beliefs, opinions, and behaviors are based on the people's belief. Therefore, it is important to build a positive belief in life so that it can strengthen people's way of thinking.

The cultural poverty that is closely related to the values, attitudes, mentality, and behavior of a person in addressing the problems of the economic constraints faced seems to be the biggest obstacle in the poverty reduction in Karangasem Regency. This phenomenon can be seen from the initial search in several regions which, according to statistical data, has the highest number of people with low economic income in Karangasem Regency as follows.

First, the community's view of life, the way of thinking or values that develop have the potential to drive people into poverty. These views of life or values include: "Sampun nasibe lacur, masih mati sing ngaba kesugihan, diapin sugih diapin lacur masih kompor meragatang, diapin sugih sing karwan maan suargan." Its translation is, "Being poor is already our fate, yet also (if we are) dead there is no wealth 
to take along, either rich or poor, in death (we) are equally burnt (within the cremation ceremony), Even (if we are) rich there is no guarantee of getting into heaven." What this thought implies is that material wealth is not important in this life. The value aspect or the way of thinking such as the above example leads to a preponderance of accepting fate, always oriented towards the past and not progressing into the future.

Second, the mentality of many of the poor to want to obtain money in the shortest time possible rather than sloughing and obtaining the rewards in due time often leads to setbacks in the government's empowerment programs. For example, providing seed money to raise pigs or cows to the target group is often unsuccessful because the livestock are more likely to be sold for fast cash rather than be kept or cultivated. In addition money from the sales are not directed to productive activities but tend to be spent on consumptive purposes.

Third, the mentality of the poor who want to maintain their poverty conditions in order to receive the benefits from government poverty alleviation programs, such as home surgery assistance, assistance from rural joint venture groups, urban joint venture assistance, assistance to improve family welfare through community empowerment programs, assistance with integrated farming systems (Simantri), cash direct assistance (BLT), poor rice assistance (raskin), people's business credit programs (KUR), regional credit guarantee programs (Jamkrida), and so forth. This is indicated by data from the Karangasem Regency Social Service that the number of poor people tends to increase whenever the government launches a cash assistance program. This indicates that government programs aimed at making the poor more empowered, in fact, may have the unintended effect of making the poor more spoiled and dependent.

Fourth, there seems to be a fatalistic or lazy attitude inherent in the part of the target group, accompanied by a certain apathy and ignorance, with a desire for pragmatic needs and wants to be met easily and quickly. Added to this are obligatory communal religious activities that are of considerably long duration. In such instances, as the affected group gets involved in village projects, often they may not properly appropriate the amount of time, energy and costs needed to manage these activities. This situation causes them to further lose opportunities that otherwise can be spent on paid work. As entertainment and a past time, it is not uncommon for gambling activities to take place, especially the tajen (cock fighting) in the day and playing cards (ceki) in the evening. In combination, much time and money are spent by the poor on the abovementioned activities, while at the same time not earning any income. This phenomenon is found in all sub-districts throughout the 
Karangasem Regency.

Fifth, many men in the target group choose to become homeless while taking up begging as their livelihood, and more often that not involving women and minors in these endeavors. In general, many local Hindus are known not to be too fond of working, while at the same time have the tendency to drink liquor and gamble. Thus, begging can be seen as an attractive and easier way for many poor local Hindus to support themselves. In fact, for the poor income earners who may already be holding down some form of paid work, upon comparing their hard-earned money with the " easy" money that beggars obtain, it is not uncommon for a percentage of them to be influenced or persuaded to join organised "begging" groups and eventually take up street begging. This phenomenon is found throughout the Kubu District area, especially in the Desa Pakraman Munti Gunung and Desa Pakraman Pedahan. Street begging is regarded as a social problem, in particular in the Karangasem Regency with its impact growing and spreading into other districts and cities in Bali every year. The situation is so dire that Karangasem Regency is said to be a "beggar supplier" in Bali.

The five indicative factors explained above provide an interesting perspective to study the phenomenon cultural poverty in Karangasem Regency. According to Suparlan
(1988: xviii), the cultural poverty and the culture of poverty are difficult to separate when poor people preserve sub-cultures (habits) that make them comfortable in the condition of poverty.

\section{Discussion}

\section{Causes of Cultural Poverty of Hindus in Karangasem Regency}

(1) Domino Effect of Economic Poverty

The cause of the cultural poverty of the Hindu people in Karangasem Regency is the domino effect of the economic poverty. The cultural poverty occurs because the economic poverty faced since birth makes it difficult for the poor to have access to jobs that make it possible for them to improve their economic status. One consequence of this is the idea of resigning to fate or destiny. For many of the poor, this idea is embedded in the mental structure because they feel it is impossible to do another business. Low savings causes another domino effect due to the economic limitations whereby the poor can barely set aside money for saving. Family planning is the next domino effect. When economic constraints make it difficult to access consumptive entertainment that requires spending some money, many married couples thus divert their desire for pleasure to the gratification of sex, thus, lack of family planning leading to many children with no means of stable earnings ability to support the growing family is also a marked weakness 
among the poor.

\section{(2) Low Transformative Awareness}

The low level of transformative awareness is also the cause of the occurrence of cultural poverty, namely the awareness to change the conditions faced at the present time to become better in the future. Transformative awareness emphasizes intentions, willingness, and efforts to make the most of opportunities to make changes for the better. Therefore, a low level of transformative awareness reflects poor intention, lack of will, and little efforts of the poor to get out of the poverty 'comfort zone'. That is, when the condition of poverty is seen to provide pragmatic momentary benefits, the transformative actions are actually seen to be deterrence in achieving these desirable benefits. This low transformative awareness ultimately gets imbedded into the mindset that poverty is a favorable condition that serves them in pragmatic ways such that this thinking creates apathy towards change.

\section{(3) The Hegemony of the Social and Political Systems}

The hegemonic social system reflects a form of reasoning within the community to accept various systemic rules through consensus or mutual agreement. The strong hegemony of the social system shapes the cognitive and mental structures of the poor such that abiding by the rules in the system will give them greater benefits, rather than if they are against it. Paying fines (dedosan), being excluded (kasepekang), and not getting a grave (setra) are seen as extremely heavy social sanctions so that they are better off following the rules set out in their social system.

In practical day-to-day reality, the hegemony of the social system can be seen from the attitudes and behavior of the poor in implementing ngayah (social service) activities that involve all the indigenous customs. Outwardly the affected group takes part in these social service activities with passionate devotion and laughter. In spite of their economic limitations and the burden of supporting themselves and their families, it is at the place of worship that they appear to find happiness and 'free' from the burdens of life. This aids in confirming the power in the hegemony of the social system to inculcate the attitudes and behavior of the poor Hindu locals in Karangasem Regency who tend to prioritize communalism, rather than making individual efforts to increase their economic standing.

In addition, the prevailing political system also contributes no less importance to the occurrence of cultural poverty in Karangasem Regency. This can be observed in the electoral political system and various poverty reduction policies that seem to place the poor as political objects, rather than subjects. In an electoral political system in which 
the political power is determined by the number of voters, then the voice of the poor is seen as quite important for the politicians. For this reason, the politicians like competing for the attention and sympathy of the poor by providing direct incentives along with political promises. This builds up a stigma along with hopeful expectations within their mentality that election years are significant for the main reason that they garner gratuitous benefits for them in the form of aids and other incentives.

Another reason for the cultural poverty of Hindus in the Karangasem Regency is the hegemony of the social and political system. The social system that applies in the Balinese adat system turns out to become obstacles for some poor Hindus to get out of the comfort zone of poverty because of their submission to the rules of the system and the fear of sanctions. Gradually, this condition forms the attitude among the poor that staying in the comfort zone is the best choice, although it is often counterproductive with efforts to get them out of the conditions of poverty. Meanwhile, the prevailing political system negatively reinforces the mental attitude of the poor who are happy to depend on the help of others and so they find little need to strengthen their work ethic.

\section{(4) Disorientation of Religious}

\section{Traditions}

The recent phenomenon shows that the implementation of a masterpiece that spends hundreds of millions to billions of rupiah and takes months to take place is quite widespread in Karangasem Regency. To fund such ceremonies, funding sources typically come from the government, donors, and from non-governmental organizations (NGOs) in the form of contributions. Usually, locals are also asked to participate in contributing their energy as a show of support from event preparation until the end. Here, the role of the traditional and religious leaders is extremely strong in regulating the implementation of the ceremony.

In the context of the occurrence of the cultural poverty, it turns out that holding of religious ceremonies avert the risk of neglecting the interests of the poor, especially in the establishment of rules and obligations made by the traditional elites or the work committees. The same goes for the ngayah schedule, which takes a lot of time for the poor to work .

The disorientation of the religious traditions leads to individual and social-cultural poverty. Individually, the disorientation of the religious traditions gives birth to ceremonial practices that exceed abilities and make religious ceremonies a momentum to seek cursory satisfaction. Socially, the disorientation of religious traditions is characterized by the implementation of religious ceremonies that do not fully 
accommodate the capabilities of the poor and legitimize the emergence of other activities that are contrary to the substance of the religious ceremony itself.

\section{Forms of Hindu Cultural Poverty in Karangasem Regency}

\section{(1) Cultural Poverty in the Individual}

\section{Domain}

Cultural poverty in the individual domain reflects the values, the attitudes, and the behavior of the individuals in responding to the real conditions of poverty. The cultural poverty in the individual domain such as (a) resigning themselves to their destiny, namely to assume that the poverty is their destiny that cannot be changed so that they can only surrender to it or accept it; (b) Apathy and a pragmatic attitude, namely apathy is formed from the view that work cannot change one's destiny, therefore the poor are indifferent to their lives and become lazy to work. As compensation for this apathy, a pragmatic attitude also appears, characterized by habitual patterns that prioritize things that are considered practical and can be enjoyed immediately without going through the work process that takes into account a considerable length of duration, energy and continuous efforts; (c) Being dependent on the assistance of other parties, which is closely related to the laziness to work, making their poverty condition a way of attracting sympathy from others to gain them pragmatic benefits. In addition, this reliance on the help of other parties also forms the habit of begging as a source of income without having to work. This behavior is maintained through practical rationality so that the condition of poverty is considered beneficial for them in order to receive much assistance with enjoyable results without having to work hard.

\section{(2) Cultural Poverty in the Family Domain}

Cultural poverty in the family domain of Hindus in Karangasem Regency can be seen in: 1) Weak family planning, characterized by a large number of family members without being balanced with sufficient capacity to meet daily needs, education, and health. In the end, the number of family members adds to the economic burden of poor families and creates a chain effect on the formation of unplanned new families due to early marriage and pre-marital pregnancy; 2) Relying on women as workers, while men do not take on economic roles and tend to commit acts of domestic violence, both physically and psychologically, undoubtedly efforts to get out of poverty will be hampered; 3) Deviation of family consumption patterns, namely spending money only for the sake of gratification and not being able to delay pleasure. 


\section{(3) Cultural Poverty in the Social} Domain

Cultural poverty in the social domain can be seen in: 1) Marginal feelings, that is, feelings that make the agency capacity disappear in the poor because they do not dare to voice their interests. This is a form of cultural poverty in the social sphere because various social practices that are counterproductive to efforts to alleviate poverty do not gain control of the poor who are the subjects. The existence of various customary, social, religious, and other social institutions in Karangasem Regency which hamper the opportunity of poor people to access their income proves the weak power of the poor in social structures because of feelings of being marginalized in them; 2) Resistance to community empowerment, characterized by being reluctant to take part in empowerment programs such as coaching, counseling or skills training because it does not provide direct results that can be enjoyed. Another attitude is to accept programs given by the government, but only intended to obtain momentary pleasure, not empowered for the future; 3) The counter-productive crowd, namely gathering activities with metuakan and gambling such as metajen (doing cock fighting) meceki (card gamling) and buying lottery. These crowd activities not only eliminate the opportunity of the poor to work and earn income, but also imply that there are nuances of gambling fate because with their income they are not enough to meet their daily needs, but they dare to risk it in hope of gaining victory.

\section{Implications of the Cultural Pov- erty of the Hindus in Karangasem Regency}

\section{(1) Implications for Religion \\ Implications for religion can}

be assessed by looking at the understanding, the practice and the socio-religious life of the poor Hindus in Karangasem Regency, such as: 1) The weakness of sraddha 'thrust' and bhakti 'adherence', namely the low work ethic of the poor can also be seen as an implication of the weak understanding and practice of the Hindus on the principle of sraddha, especially the teachings of karmaphala 'deed and its fruit'. The resignation accepts the conditions of poverty as destiny, the apathy that hard work will not change fate, and the implementation of activities that are based on the transactional-religious spirit to change destiny. 2) The religious formality: it is characterized by the implementation of religious activities that are not based on concepts, understanding, or simply implementing without knowing the meaning behind the activities carried out. 3) The restructuring of the socioreligious system suggests an idea to accommodate the interests of the poor as not only to be enjoyed by the poor themselves, but all the elements 
included in the system. Therefore, the transformation of the socio-religious system that is more oriented towards decreasing the religious burden of the Hindus will become a new religious pattern that is widely accepted in the social structures.

\section{(2) Implications for Culture}

The implications of cultural poverty can be understood in the following ways: 1) inheritance of subculture of poverty can be understood that cultural poverty in the form of values, attitudes, and behaviors of the poor people inherits a subculture of poverty among the Hindu poor in Karangasem Regency. The poor build a map of their own meanings and ways of life that they believe to be true and this is perpetuated through narratives that are within the dominant culture. For example, when a dominant culture sees the importance of education for children, even the poor choose to work with them. Another example of other poverty subcultures can also be seen from the habits of poor people begging for help from others. In dominant cultures, the begging behavior is generally considered inappropriate, even embarrassing, so most people will avoid it. But this is not the case with the poor who seem to have no mental barriers to making it a job. This way of life and map of meaning are inherited and handed down cross-generation because there is no new value system that can break the chain.

2) The blockage of access to social change, meaning that ignorance of education results in low levels of public education. Inability to meet family health standards, such as the adequacy of nutrition and reproductive health give birth to poor families with large numbers of children with poor health. The mentality of being lazy, apathetic, and unproductive results in low income since these habits are preserved. The blockage of access to social change can be seen in aspects of development, circulation, and social progress. The social change tends to slow down, even stagnate because various processes of social transformation are hampered by the subculture of poverty that occurs in the realm of individuals, families, and social. The education, the economics, and the communication as the three main drivers of social change do not go well because of the cultural barriers inherent in cultural poverty.

3) The expansion of customary functions is one of the characters of the poor who is observed by the adat prajuru is more afraid of customary rules, rather than positive legal rules because of God's intervention and social sanctions in the adat system. For this reason, the role of adat in overcoming social problems is indeed quite large because the customary institutions also have members who intersect with other community members, the citizens (krama) who are Hindus. That is, the expansion of adat functions to overcome social problems, such as the 
cultural poverty, is undoubtedly carried out as a cultural movement by using the potential of adat which has the binding power for all of its families.

\section{Closing}

The cultural poverty in Karangasem Regency shows the reality of poverty caused by various factors that are intertwined with one another: the natural, structural, cultural and educative. These are the major factors in cultural poverty because of the fact that most poor people in Karangasem
Regency are illiterate, and/or the level of education is relatively low. The cultural poverty in the form of values, attitudes, and real behavior can also occur in communities that are not in the category of poor. The customary system in Karangasem Regency has great potential to participate in the efforts to overcome cultural poverty, if the cultural poverty of the Hindus in Karangasem Regency is not handled properly it can hamper the social change especially in aspects of development, circulation, and social progress.[]

\section{References}

Books

Arikunto, Suharsimi. 2002. Prosedur Penelitian Suatu Pendekatan Praktek. Jakarta: PT. Rineka Cipta.

Aziz, Abdul. 2006. Esai-esai Sosiologi Agama. Jakarta: Diva Pustaka.

Bagus, Lorenz. 2002. Kamus Filsafat. Jakarta: Gramedia Pustaka Utama.

Barker, Chris. 2005. Culture Studies Teori dan Praktik. Yogyakarta: PT Bentang Pustaka.

Black. James A. dan Dean J. Champion. 2001. Metode Dan Masalah Penelitian Sosial. Bandung: Pt Refika Aditama.

Hadiwigeno, Sutanto dan Agus Pakpahan. 1993. Identifikasi wilayah miskin di Indonesia. Jakarta: LP3ES.

Harianto, Sugeng. 2014. "Strukturisasi Kemiskinan Masyarakat Pedesaan: Studi di Desa Mulyodadi, Kecamatan Wonoayu, Kabupaten Sidoarjo, Jawa Timur”. Disertasi. Malang: Program Pascasarjana Fakultas Pertanian Universitas Brawijaya.

Harington, Michael. 1962. The Other America: Poverty in the United States. USA; Macmillan.

Kleiden, Ignas. 1987 “Masalah Kemiskinan Sosial-Budaya di Indonesia”. Prisma 16 no 8 (1987): $15-28$.

Koentjaraningrat. 2002. Kebudayaan, Mentalitas, dan Pembangunan. Jakarta: Gramedia Pustaka Utama.

Lalintihan Babad Karangasem, milik Almarhum I Gusti Agung Jelantik, Puri Agung Jelantik Kelodan Pesagi Karangasem.

Lewis, Oscar. 1988. Kisah Lima Keluarga: Telaah-telaah Kasus Orang Meksiko dalam Kebudayaan Kemiskinan. Yayasan Obor Indonesia: Jakarta.

Lewis, Oscar. 1996. The Culture of Poverty, dalam G. Gmelch dan W. Zenner, eds. Urban Life. 
Waveland Press.

Made Kertha Adhi, I Ketut Ardhana, dan I Made Maduriana. 2016. "Faktor-faktor Penyebab Kemiskinan Kultural dan Model Pengentasannya Berbasis Kearifan Lokal: Studi Pada Masyarakat Miskin di Pegunungan Kintamani, Bangli”. Dalam Jurnal Kajian Bali Vol. 06, No. 02, Oktober 2016.

Philip, Hauser M \& Le Gater, Richard. 1981. Displacement: How to Fight it, The Study of Urbanization. Newyork: Wiley.

Sudiarta, I Nyoman dan I Wayan Suardana. 2016. "Dampak Pariwisata Terhadap Kemiskinan di Kawasan Pariwisata di Bali" dalam Jurnal Kajian Bali Vol. 06, No. 02, Oktober 2016.

Sudibia, I Ketut dan A.A. Istri Ngurah Marheni. 2012. "Beberapa Strategi Pengentasan Kemiskinan di Kabupaten Karangasem, Provinsi Bali” dalam Jurnal Piramida Vol. IX. No.1: 1-14.

Sugiyono, 2010. Metode Penelitian Pendidikan (Pendekatan Kuantitatif, Kualitatif dan R\&D). Bandung : Alfabeta.

Sura, I Gde. dkk. 2002. Kamus Agama Hindu. Denpasar: Pemerintah Provinsi Bali.

Tim Penyusun. 2013. Meminimalisasi Kemiskinan Kultural di Kabupaten Karangasem. Amlapura : Bagian Kesra Setda Kabupaten Karangasem.

Triguna, Ida Bagus Gde Yudha. 1997. "Pengaruh Mobilitas Kelas dan Konflik Terhadap Penafsiran Kembali Simbolisme Masyarakat Hindu di Bali”. Disertasi - tidak dipublikasikan. Bandung: Universitas Padjajaran.

.2008. Kebudayaan dan Modal Budaya Bali dalam Tropong Lokal, Nasional, Global. Denpasar: Widya Dharma. . 2011. Mengapa Bali Unik. Jakarta: Pustaka Jurnal keluarga.

Usman, Sunyoto. 2004. Pembangunan dan Pemberdayaan Masyarakat. Yogyakarta: Pustaka Pelajar.

Utama, I Wayan Budi.2013. Agama dalam Praksis Budaya. Denpasar : Program Pascasarjana Universitas Hindu Indonesia.

Warna, I Wayan (at al). 1986. Babad Dalem: Teks dan Terjemahan (A-B: Periode Samprangan s/d Gelgel. - Babad C: periode Klungkung). Denpasar: Dinas Pendidikan dan Kebudayaan Propinsi Daerah Tk. I Bali. 